\title{
Phenols content and 2-D electrophoresis protein pattern: a promising tool to monitor Posidonia meadows health state

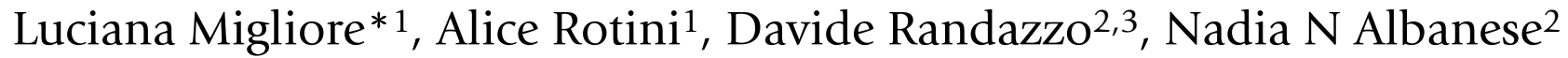 and Agata Giallongo ${ }^{3}$
}

Address: ${ }^{1}$ Università "Tor Vergata", Dipt. Biologia, Via della Ricerca Scientifica, I-00133 Roma, Italy, ${ }^{2}$ Università di Palermo, Dipt. Oncologia Sperimentale e Applicazioni Cliniche, 90146 Palermo, Italy and ${ }^{3}$ Istituto di Biomedicina e Immunologia Molecolare, Consiglio Nazionale delle Ricerche, 90146 Palermo, Italy

Email: Luciana Migliore* - luciana.migliore@uniroma2.it; Alice Rotini - alice.rotini@virgilio.it; Davide Randazzo - bio_davide@libero.it; Nadia N Albanese - nadiaalbanese@yahoo.it; Agata Giallongo - giallongo@ibim.cnr.it

* Corresponding author

Published: 30 July 2007

BMC Ecology 2007, 7:6 doi:10.1 186/1472-6785-7-6
Received: 9 March 2007

Accepted: 30 July 2007

This article is available from: http://www.biomedcentral.com/l472-6785/7/6

(C) 2007 Migliore et al; licensee BioMed Central Ltd.

This is an Open Access article distributed under the terms of the Creative Commons Attribution License (http://creativecommons.org/licenses/by/2.0), which permits unrestricted use, distribution, and reproduction in any medium, provided the original work is properly cited.

\begin{abstract}
Background: The endemic seagrass Posidonia oceanica (L.) Delile colonizes soft bottoms producing highly productive meadows that play a crucial role in coastal ecosystems dynamics. Human activities and natural events are responsible for a widespread meadows regression; to date the identification of "diagnostic" tools to monitor conservation status is a critical issue. In this study the feasibility of a novel tool to evaluate ecological impacts on Posidonia meadows has been tested. Quantification of a putative stress indicator, i.e. phenols content, has been coupled to 2-D electrophoretic protein analysis of rhizome samples.

Results: The overall expression pattern from Posidonia rhizome was determined using a preliminary proteomic approach, 437 protein spots were characterized by $\mathrm{pl}$ and molecular weight. We found that protein expression differs in samples belonging to sites with high or low phenols: 22 unique protein spots are peculiar of "low phenols" and 27 other spots characterize "high phenols" samples.

Conclusion: Posidonia showed phenols variations within the meadow, that probably reflect the heterogeneity of environmental pressures. In addition, comparison of the 2-D electrophoresis patterns allowed to highlight qualitative protein expression differences in response to these pressures. These differences may account for changes in metabolic/physiological pathways as adaptation to stress. A combined approach, based on phenols content determination and 2-D electrophoresis protein pattern, seems a promising tool to monitor Posidonia meadows health state.
\end{abstract}

\section{Background}

Posidonia oceanica (L.) Delile (fig. 1) is a Mediterranean endemism. Plants colonize soft bottoms producing large meadows that span from the sea surface to 35-40 m depth. Meadows are highly productive ecosystems, as they produce high amount of oxygen and organic compounds, sustain complex food nets, act as a nursery/refuge for several species. They also play a crucial role in coastal preservation, by stabilizing sediments and reducing hydrodynamics effects (see fig. 1) [1,2]. 


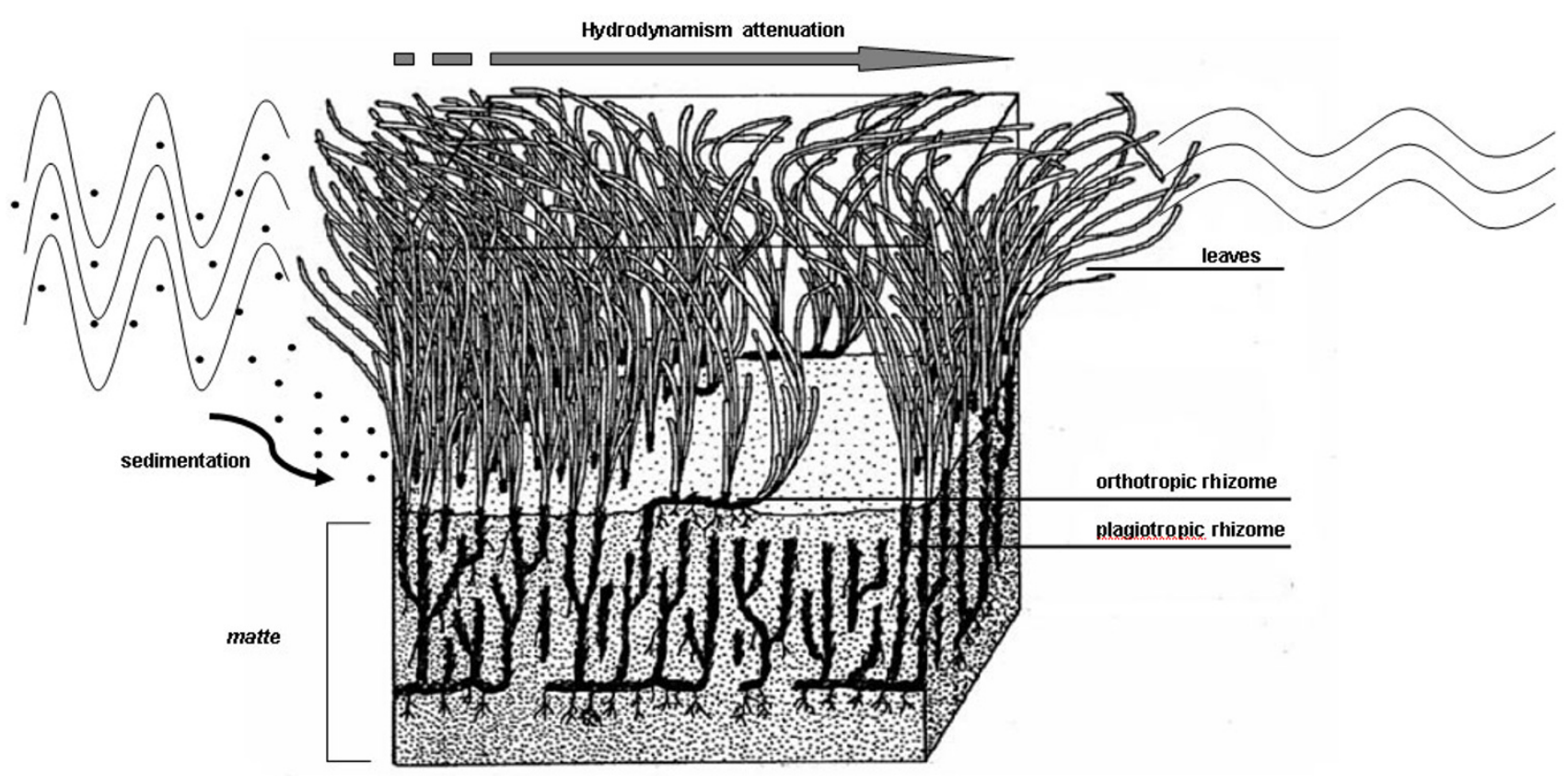

Figure I

Schematic representation of Posidonia meadow (matte, rhizomes and leaves) and its effect on sediment stabilization and reduction of hydrodynamism (modified from Boudouresque and Meinesz [55]).

Many human activities and natural events are responsible for the widespread meadows regression, such as modified hydrogeological regime and littoral transport [3-6], pollution [7-11], aquaculture [12-15], trawling [16,17], anchorages [18-21], placing of cable/pipes or damping $[22,23]$, in addition to grazing, sea storms, climatic changes, etc. [24-26]. All lead to alterations of Posidonia ecosystems.

Phenolic compounds are widespread secondary metabolites in plants. They play a role in herbivore/pathogen protection $[27,28]$ and are considered stress indicators in terrestrial plants [29-38]. Phenols compounds have been identified in marine phanerogames [39-41] and high concentrations of phenolic compounds in Posidonia leaves were found in a few cases a) under competition with Caulerpa taxifolia [42,43], b) under mercury contamination $[44]$, c) nearby offshore aquaculture cages [45]. An attempt to identify specific phenolic compounds in Posidonia leaves in response to different environmental pressures did not give clear-cut results [46]. This may be due to the fact that Posidonia leaves are temporary structures with a relatively short lifespan (about 7 months) at the Mediterranean mid-latitudes. Therefore they show marked seasonal fluctuations in common physiological processes - including synthesis and accumulation of phenolic compounds [47]. Rhizomes have a lifespan much longer than leaves: consequently, they undergo less marked fluctuations and may carry the memory of experienced environmental pressures.

The 2-D electrophoresis protein analysis produces maps of all the expressed proteins, in a given time and under a specific environmental condition. The protein pattern is a dynamic entity varying from cell to cell in the same organism, it is constantly modulated by external and internal signalling and reflects changes in the physiological state. The proteomic approach, based on the simultaneous separation of hundreds of proteins in the same 2D-electrophoretic gel, represents a powerful tool to monitor the "health state" of ecosystems, by comparing quantitative/ qualitative pattern differences of protein expression in organisms living in polluted/non-polluted areas.

In this work we choose the rhizome, in particular the basal section, as the most reliable plant portion to evaluate possible alterations of both phenols content and protein expression.

The aim of this study was to verify the feasibility of phenols quantification coupled to 2-D electrophoretic protein analysis in rhizomes, as a novel "diagnostic" tool to monitor Posidonia meadows conservation status. 


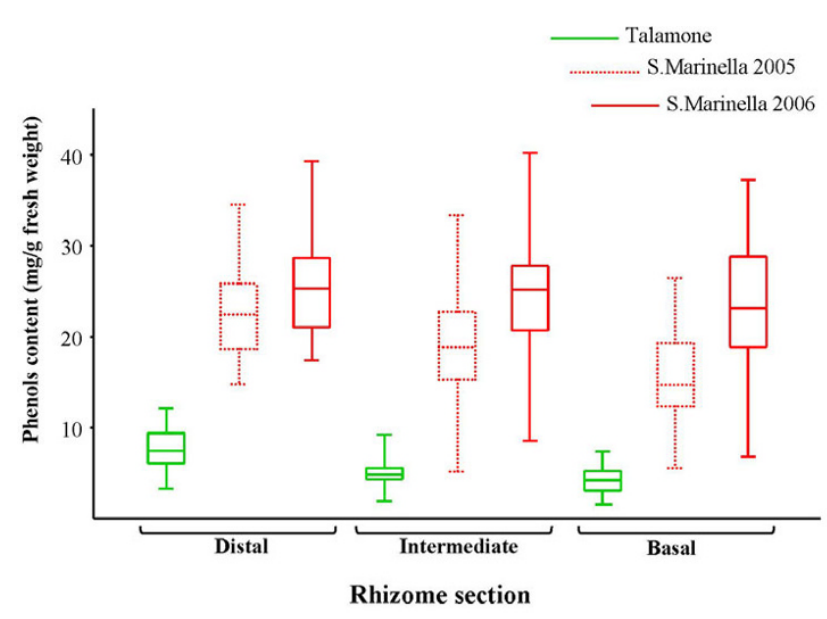

Figure 2

Distribution of phenols content in rhizome distal, intermediate and basal sections. Phenols values $(\mathrm{mg} / \mathrm{g}$ fresh weight) are represented as box-plots: the box contains $50 \%$ data (the extremes of that box are the QI and Q3, Ist $^{\text {st }}$ and $3^{\text {rd }}$ quartiles), the internal horizontal segments represent median of the distributions (Q2 value, $2^{\text {nd }}$ quartile), 'whiskers' range from the lowest to the highest value. The box plots from S. Marinella meadow samples collected in 2006 (red, solid line) and 2005 (red, dotted line), and from Talamone meadow samples (green) are reported.

\section{Results and discussion Phenols content}

Total phenols were measured in distal, intermediate and basal sections of sampled rhizomes. Mean value $(\mathrm{mg} / \mathrm{g}$ fresh weight) of the distal sections was $25.6(n=60$; SE 1.1) ranging from 18.9 to 35 , intermediate sections mean was $25.1(\mathrm{n}=60 ; \mathrm{SE} 1.1)$ ranging from 15.3 to 36.7 and basal sections mean was $23.7(\mathrm{n}=60 ;$ SE 1.4$)$ from 7.1 to 35.2 .

Data of total phenols content in samples collected in 2006 from the S. Marinella meadow were compared to data previously obtained with identical experimental procedure from rhizomes of the same meadow collected in 2005 and from rhizomes of the Talamone meadow (Grosseto, Italy, 2002). Samples from the well preserved meadow of Talamone [54] showed the lowest and less scattered phenols values, samples from the S. Marinella meadow (year 2006) showed highly scattered values (Fig. 2 ). We found that the overall phenols content in S. Marinella-2005 samples was lower than the content detected in 2006 samples, however in both cases values were higher than the ones obtained from the Talamone samples (compare box-plots in Fig.2).
Phenols content differences between Talamone and S. Marinella-2006 samples are statistically significant for all the sections (Mann-Whitney, p $<<0.001$ ), differences between S. Marinella-2005 and S. Marinella-2006 samples are highly significant for basal and intermediate sections (Mann-Whitney, p $<<0.001$ ), significant for the distal section (Mann-Whitney, $\mathrm{p}=0.00146$ ). The lowest phenols content may be consistently associated with the good health state of the Talamone meadow [53].

In this study on the S. Marinella meadow the three lowest phenols contents found in rhizome basal sections were: $7.1 \mathrm{mg} / \mathrm{g} \pm 0.5,14.4 \mathrm{mg} / \mathrm{g} \pm 0.2$ and $14.5 \mathrm{mg} / \mathrm{g} \pm 0.8$; the three highest were: $28.9 \mathrm{mg} / \mathrm{g} \pm 0.2,33.6 \mathrm{mg} / \mathrm{g} \pm 2.0$ and $35.2 \mathrm{mg} / \mathrm{g} \pm 2.8$. Posidonia shoots from these six sampling sites were chosen for protein analyses.

\section{Protein analysis}

In order to assess a possible match between different phenols content and variations in protein expression, at first we determined the overall expression pattern of Posidonia rhizome by 2-D electrophoresis. The polypeptides falling within the experimental window of pI 3-9 and 12-200 $\mathrm{kDa}$ and sufficiently abundant to be detected by the silver staining procedure were taken into account. Protein patterns from low and high phenols samples were combined and the experimental values of $\mathrm{p} I$ and molecular weight for each isoelectric spot were calculated by a dedicated computer software using reference proteins with known $\mathrm{pI}$ and molecular weight, commonly called "anchors" (see Materials and Methods section). Proteins, accounting for a total of 437 spots, ranged from $\mathrm{p} I 5.11$ to $\mathrm{pI} 8.66$ with an apparent molecular weight ranging from $13306 \mathrm{Da}$ to 95563 Da (see additional file 1).

Two representative 2-D gels from low and high phenols are shown in Fig. 3. Computer-assisted cross-comparison revealed qualitative differences that accounted for differentially expressed proteins: 22 spots are peculiar of low phenols whereas 27 spots characterize high phenols samples, accounting for 5.0 and $6.4 \%$ of the entire map, respectively. These differences were consistently found in all the examined samples.

At low phenols content, differentially expressed proteins ranged from $\mathrm{p} I 5.85$ to $\mathrm{p} I$ 8.30, with an apparent molecular weight ranging from $18122 \mathrm{Da}$ to $87009 \mathrm{Da}$. In high phenols samples, isoelectric point of differentially expressed proteins was comprised between $\mathrm{pI} 5.22$ and $\mathrm{pI}$ 8.64, with an apparent molecular weight from $13306 \mathrm{Da}$ to 95563 Da (Table 1).

Although an identity was not assigned to the differentially expressed polypeptides, they have been firstly characterized by assigning a molecular mass and a total charge. 


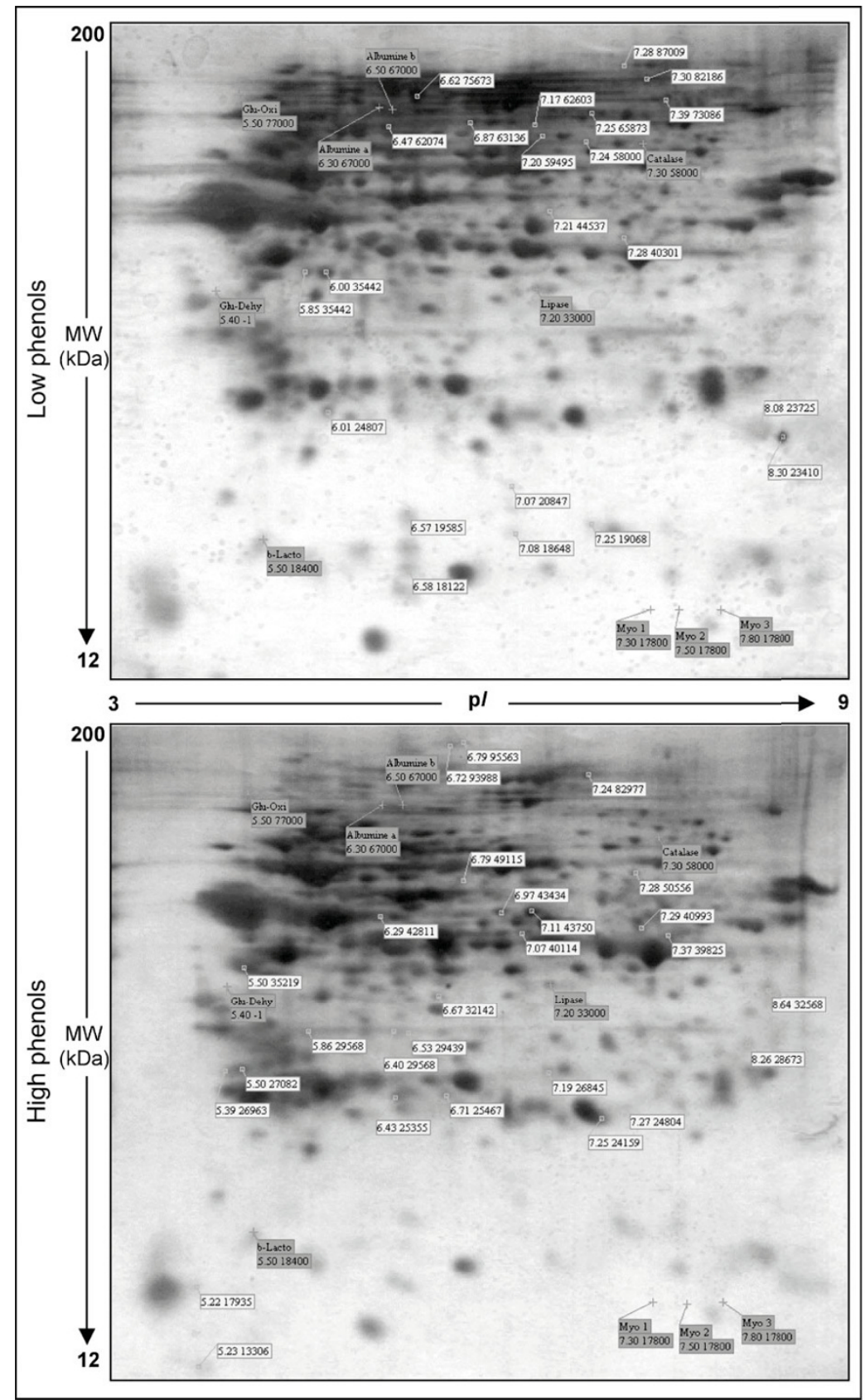

\section{Figure 3}

Representative 2-DE patterns of Posidonia rhizome proteins. Upper panel, proteins isolated from low phenols samples. Lower panel, proteins isolated from high phenols samples. About $15 \mu \mathrm{g}$ of proteins from dry powder of Posidonia rhizome were separated on IPG gel strip (7 cm, 3-10 NL) followed by SDS-PAGE on a vertical mini-gel (I2\%T). Peculiar protein spots are labelled, $\mathrm{pl}$ and molecular weight values are indicated (white background). Positions of protein markers are indicated and labelled with name and pl/molecular weight values (gray background). Protein markers (in alphabetic order) are: Albumine a; Albumine b; Catalase; Glucose-I-Dehydronase (Glu-Dehy); Glucose oxidase (Glu-Oxi); $\beta$-Lactoglobuline (b-Lacto); Myoglobine subunits (Myo I, Myo 2, Myo 3). Numbers on the left refer to the position of the molecular weight standards and numbers in the middle indicate the $p /$ range. 


\section{Conclusion}

It has been suggested that phenols content is an indicative trait of environmental stress in Posidonia oceanica [42$47,53]$. In this work we choose the rhizome basal section as the most reliable material to measure this putative marker of ecosystem imbalance. The Posidonia shoots utilized in this study showed that variations in the phenols content exists within the examined meadow (S. Marinella, Italy), probably reflecting environmental pressures heterogeneity. Moreover, comparison of phenols content in the same meadow at one year time distance showed an increase in the overall values.

We have constructed the first 2-D electrophoretic map of Posidonia oceanica rhizome, made of 437 protein spots, characterized by $\mathrm{p} I$ and molecular weight.

Usually, the bi-dimensional protein pattern is typical of the physiological state and varies under different environ-

Table I: Peculiar protein spots identified in the 2-D electrophoretic maps of low phenols (22 spots) and high phenols (27 spots) Posidonia rhizome samples

\begin{tabular}{|c|c|c|c|}
\hline \multicolumn{2}{|c|}{ Low phenols } & \multicolumn{2}{|c|}{ High phenols } \\
\hline $\mathrm{pl}$ & $M W(D a)$ & $\mathrm{pl}$ & $M W(D a)$ \\
\hline 5.85 & 35442 & 5.22 & 17935 \\
\hline 6.00 & 35442 & 5.23 & 13306 \\
\hline 6.01 & 24807 & 5.39 & 26963 \\
\hline 6.47 & 62074 & 5.50 & 35219 \\
\hline 6.57 & 19585 & 5.50 & 27082 \\
\hline 6.58 & 18122 & 5.50 & 28926 \\
\hline 6.62 & 75673 & 5.86 & 29568 \\
\hline 6.87 & 63136 & 6.29 & 42811 \\
\hline 7.07 & 20847 & 6.40 & 29568 \\
\hline 7.08 & 18648 & 6.43 & 25355 \\
\hline 7.17 & 62603 & 6.53 & 29439 \\
\hline 7.20 & 59495 & 6.67 & 32142 \\
\hline 7.21 & 44537 & 6.71 & 25467 \\
\hline 7.24 & 58000 & 6.72 & 93988 \\
\hline 7.25 & 65873 & 6.79 & 95563 \\
\hline 7.25 & 19068 & 6.79 & 49115 \\
\hline 7.28 & 87009 & 6.97 & 43434 \\
\hline 7.28 & 40301 & 7.07 & 40114 \\
\hline 7.30 & 82186 & 7.11 & 43750 \\
\hline 7.39 & 73086 & 7.19 & 26845 \\
\hline 8.08 & 23725 & 7.24 & 82977 \\
\hline \multirow[t]{7}{*}{8.30} & 23410 & 7.25 & 24159 \\
\hline & & 7.27 & 24804 \\
\hline & & 7.28 & 50556 \\
\hline & & 7.29 & 40993 \\
\hline & & 7.37 & 39825 \\
\hline & & 8.26 & 28673 \\
\hline & & 8.64 & 32568 \\
\hline
\end{tabular}

The experimental values of $\mathrm{pl}$ and molecular weight (MW) for every isoelectric spot were calculated with ImageMaster 2D Platinum System. mental conditions. Thus, the patterns comparison allows the highlighting of protein expression differences in response to stresses. Here we showed, by comparison of samples belonging to sites with low or high phenols content, that certain protein spots present in "low phenols" are absent in "high phenols" and vice versa. This may account for changes in metabolic/physiological pathways as adaptation to stress, including activation/repression of coordinate sets of genes. Differences cover the 5-6\% of the entire protein map and match the plants phenols response. To the best of our knowledge, this is the first attempt to correlate the pattern of expressed proteins to a putative stress indicator, such as phenols content, in Posidonia rhizome.

Although the identification of each protein spot needs further investigation and might be hampered by the lack of extensive database information, the combined approach, based on phenols content determination and 2-D electrophoresis protein pattern, seems a promising tool to monitor Posidonia meadows health state.

\section{Methods}

\section{Sampling, conservation and sample selection}

Posidonia oceanica was sampled from the Santa Marinella meadow (Rome, Italy), Site of Community Importance (according to Habitat Directive 92/43/EEC), spanning from Capo Linaro to Santa Severa, for a $13.5 \mathrm{~km}$ coastline and covering a surface of 1,800 ha.

Shoots were sampled in May 2006 in 20 randomly chosen sites (depths from 7.5 to $13.5 \mathrm{~m}$ ). At least 4 orthotropic shoots per sampling site were collected and maintained at $4^{\circ} \mathrm{C}$ in the dark until the arrival to the laboratory. Plants were first rinsed in 0.1 Triton-X (Sigma) and then in distilled water to remove epiphytes and contaminants.

At least 3 shoots per site were stored at $-20^{\circ} \mathrm{C}$ until processing for phenol analysis, and at least 1 at $-80^{\circ} \mathrm{C}$ for protein analyses. Total phenols concentration was determined in duplicate on three different rhizomes for sampling site according to Folin-Ciocalteau procedure [48], each shoot was dissected into three sections (about $1 / 3$ of the total length): basal, intermediate and distal; about 125 mg fresh weight of each section were separately processed. Once established the sampling sites in which the three highest and lowest phenols values were found, shoots from these sampling sites were selected for protein analysis.

\section{Protein extraction and electrophoresis}

Protein were extracted according to the Wang et al. [49] protocol originally developed for recalcitrant plant tissues (leaves and flesh). This protocol, previously utilized for 
Posidonia leaves [50], was modified for Posidonia rhizomes.

Briefly, frozen rhizomes were peeled off to remove all cortical tissues, and a piece of the basal section (250 mg) was ground in liquid $\mathrm{N}_{2}$ using a mortar with pestle. The powdered tissue was subjected to phenols extraction in the presence of SDS, as described [49].

The protein pellet was dried and dissolved in 2-DE rehydration solution [8 M urea, $2 \mathrm{M}$ thiourea, 2\% CHAPS, 50 mM dithiothreitol (DTT), 0.2\% carrier ampholytes (3-10 Bio-Lyte Ampholyte, Bio-Rad Laboratories)], supplemented with proteases and phosphatases inhibitors (Sigma). Protein content was measured by Bradford protein assay (Bio-Rad Laboratories) using Bovine Serum Albumine as standard.

Protein samples $(15 \mu \mathrm{g})$ were applied in $155 \mu \mathrm{l}$ of 2-DE rehydration solution to $7 \mathrm{~cm}$ Readystrip IPG (Immobilized pH Gradient, pH 3-10 NL, Bio-Rad Laboratories), by incubating overnight. The isoelectrofocusing (IEF) was performed at room temperature using the ZOOM IPG Runner $^{\mathrm{TM}}$ Mini-cell (Invitrogen), applying $500 \mathrm{~V}$ for $4 \mathrm{hrs}$ (1 mA/strip; $0.5 \mathrm{~W} /$ strip).

Focused strips were equilibrated using DTT and iodoacetamide solutions, positioned on a $12 \%$ acrylamide SDSPAGE minigel $1 \mathrm{~mm}$ thick [51], according to standard procedures. After electrophoresis, resolved proteins were visualized by acidic silver staining that allows to detect as low as $0.5-1 \mathrm{ng}$ of protein per spot [52]. Proteome $\mathrm{pI}$ markers were from SERVA Electrophoresis (Heidelberg). Each protein sample was subjected at least to 2 parallel runs of isolectrofocusing and second dimension electrophoretic separation to assess proteomic pattern reproducibility.

\section{Image processing and data analysis}

Silver-stained gels were digitised using a Trust EasyConnect 19200 scanner, generating $2.4 \mathrm{Mb}$ images. The images were saved as Tiff format and imported into the ImageMaster 2-D Platinum software (Amersham, version 6.0). Spot selection was performed using default selection parameters [53]. For the attribution of isoelectric points and relative molecular masses we utilized as internal standard a mixture of 10 protein with known identities (see Fig. 3 and related legend).

\section{Authors' contributions}

LM and AG conceived and designed the study. AR sampled plants. AR and DR carried out the laboratory analyses, and analysed the data. NNA processed 2-DE images. LM and AG wrote the manuscript with help from AR and DR. All authors read and approved the final manuscript.

\section{Additional material}

\section{Additional file 1}

List of the 437 protein spots identified from Posidonia rhizome. The experimental values of $\mathrm{pI}$ and molecular weight $(\mathrm{MW})$ for every isoelectric spot were calculated with ImageMaster 2D Platinum System. The percent of each spot with respect to the total spots volume is also reported. Click here for file

[http://www.biomedcentral.com/content/supplementary/14726785-7-6-S1.xls]

\section{Acknowledgements}

The authors are grateful to $E$ Fresi for the introduction to the fantastic world of Posidonia. Thanks also go to M Scardi e L Valiante for samples collection. We are also grateful to I Pucci-Minafra for her insightful comments. This work was supported by CNR/MiUR funds to AG; ECON grant by commitment of ENEL Produzione S.p.A. (n. 30000438I4/2004) and 60\% grant from University of Tor Vergata to LM.

\section{References}

I. Mazzella L, Scipione B, Gambi MC, Fresi E, Buia MC, Russo F, De Maio $R$, Lorenti M, Rando A: Le praterie sommerse del Mediterraneo. Stazione Zoologica, Napoli, Pubblicazione a cura del laboratorio di Ecologia del Benthos; 1986.

2. Arata P, Diviacco G: Importanza delle praterie di Posidonia oceanica nel sistema marino costiero edegli interventi per la loro salvaguardia. Acqua Aria 1989, 5:555-57I.

3. Astier JM: Impact des aménagements littoraux de la rade de Toulon, liés aux techniques d'endigage, sur les herbiers à Posidonia oceanica. In International Workshop on Posidonia oceanica beds Volume I. Edited by: Boudouresque CF, Jeudy De Grissac, A, Olivier J. France: GIS Posidonie publications; 1984:255-259.

4. Blanc JJ, Jeudy De Grissac A: Réflexion géologique sur la régression des herbiers à Posidonies (départements du Var et des Bouches-du-Rhône). In Second international Workshop on Posidonia beds Volume 2. Edited by: Boudouresque CF, Meinesz A, Fresi E, Gravez V. France: GIS Posidonie publications; 1989:273-285.

5. Guidetti P, Fabiano M: The use of lepidochronology to asses the impact of terrigenous discharges on the primary leaf production of the Mediterranean seagrass Posidonia oceanica. Mar Poll Bull 2000, 40(5):449-453.

6. Ruiz JM, Romero J: Effects of disturbances caused by coastal constructions on spatial structure, growth dynamics and Photosynthesis of the seagrass Posidonia oceanica. Mar Poll Bull 2003, 46: I523-1533.

7. Pérès JM, Picard J: Causes de la raréfaction et de la disparition des herbiers de Posidonia oceanica sur les côtes françaises de la Méditerranée. Aquat Bot 1975, I(2): |33-139.

8. Pérès JM: La régression des herbiers à Posidonia oceanica. In International Workshop on Posidonia oceanica beds Volume I. Edited by: Boudouresque CF, Meinesz A, Fresi E, Gravez V. France: GIS Posidonie publications; 1984:445-454.

9. Bourcier M: Régression des herbiers à Posidonia oceanica (L.) Delile, à l'Est de Marseille, sous l'action conjuguée des activités humaines et des modifications climatiques. In International Workshop on Posidonia oceanica beds Volume 2. Edited by: Boudouresque CF, Meinesz A, Fresi E, Gravez V. France: GIS Posidonie publications; 1989:287-293.

10. Pergent-Martini C, Pergent G: Impact of a sewage treatment plant on the Posidonia oceanica meadow: Assessment criteria. In Proceedings of the Second International conference on the Mediterranean coastal environment: 24-27 October 1995 Volume 95. Terragona, Spain. MEDCOAST; 1995:1389-1399.

II. Balestri E, Benedetti-Cecchi L, Lardicci C: Variability in patterns of growth and morphology of Posidonia oceanica exposed to urban and industrial wastes: contrasts with two reference locations. J Exp Mar Biol Ecol 2004, 308:I-2I. 
12. Pergent G, Mendez S, Pergent-Martini C, Pasqualini V: Preliminary data on the impact of fish farming facilities on Posidonia oceanica meadows in the Mediterranean. Oceanol Acta 1999, 22(I):95-107

13. Delgado O, Ruiz J, Perez M, Romero J, Ballesteros E: Effects of fish farming on seagrass (Posidonia oceanica) in a Mediterranean bay: seagrass decline after organic loading cessation. Oceanol Acta 1999, 22(I): 109-II7.

14. Cancemi G, De Falco G, Pergent G: Impact of a fish farming facility on a Posidonia oceanica meadow. Biol Mar Medit 2000 , 7(2):34|-344.

15. Ruiz JM, Perez M, Romero J: Effects of fish farm loadings on seagrass (Posidonia oceanica) distribution, growth and photosynthesis. Mar Poll Bull 200I, 42(9):749-760.

16. Sànchez-Lizaso JL, Guillen-Nieto JE, Ramos-Espla AA: Theregression of Posidonia oceanica meadows in EI Campello (SE Spain). Rapports et Procès-Verbaux des Réunion de la Commission internationationale pour l'Exploration scientifique de la Mèditerranèe 1990 , 32(I):7

17. Ruiz JM, Gutièrrez Ortega JM, Garcìa Charton JA, Pèrez Ruzafa $A$ Spatial characterization of environmental impact by bottom trawling on meadows in artificial reef areas of the southeastern cost of Spain. Proceedings of the Seventh International Conference on Artificial Reefs 7th CARAH 1999:664-674.

18. Porcher M: Impact de mouillages forains sur le herbiers à Posidonia oceanica. In International Workshop on Posidonia oceanica beds Edited by: Boudouresque, CF, De Grissac AJ, Oliver J Marseille. France: GIS Posidonie publications; 1984:45- I48.

19. Garcia-Charton JA, Bayle JT, Sànchez-Lizaso JL, Chiesa P, Llaurdò F, Pérez C, Djian H: Respuesta de la pradera de Posidonia oceanica y su ictiofauna asociada al anclaje de embarcaciones en el parque Nacional de Port-Cros Francia. Publ Espec - Inst Esp Oceanogr 1993, I I:423-430.

20. Francour P, Ganteaume A, Poulain M: Effects of boat anchoring in Posidonia oceanica seagrass beds in the Port-Cros Nationa Park (north-western Mediterranean Sea). Aquat Cons 1999 , 9:391-400.

21. Milazzo M, Badalamenti F, Seccherelli G, Chemello R: Boat anchoring on Posidonia oceanica beds in a marine protected area (Italy, western Mediterranean): effect of anchor types in different anchoring stages. J Exp Mar Biol Ecol 2004, 299:5 I-62

22. Peirano A, Bianchi NC: Decline of the seagrass Posidonia oceanica in response to environmental disturbance: a simulation like approach off Liguria (NW Mediterranean Sea). Proceedings of 30th European marine biological Symposium; Southampton 1995:87-95.

23. Pasqualini V, Pergent-Martini C, Pergent G: Environmental impacts identification along corsican coasts (Mediterranean Sea) using image processing. Aquat Bot 1999, 65:311-320.

24. Marbà N, Duarte CM, Cebrian J, Gallegos ME, Olesen B, Sand-Jensen $\mathrm{K}$ : Growth and population dynamics of Posidonia oceanica on the Spanish Mediterranean coast: elucidating seagrass decline. Mar Ecol Prog Ser 1996, I37:203-2I3.

25. Boudouresque CF, Giraud G, Thommeret J, Thommeret Y: First attempt at dating by ${ }^{14} \mathrm{C}$ the undersea beds of dead Posidonic oceanica in the bay of Port-Man (Port-Cros, Var, France) Trav Sci Parc nation Port-Cros, France 1980, 6:239-242

26. Boudouresque CF, Bernard G, Bonhomme P, Charbonnel E, Diviacco G, Meinesz A, Pergent G, Pergent-Martini C, Ruitton S, Tunesi L: Préservation et conservation des herbiers à Posidonia oceanica. Accord RAMOGE publications: Marseille, France; 2006

27. Swain T: Secondary compounds as protective agents. Ann Rev Plant Physiol Plant Mol Biol 1977, 28:479-50I

28. Pisani JM, Distel RA: Inter and intraspecific variations in production of spines and phenols in Prosopis caldemia and Prosopis flexuosa. J Chem Ecol I998, 24(I):23-36.

29. Contour-Ansel D, Louguet P: Variations du taux de polyphenols dans les aiguilles d'épicéa (Picea abies), présentant différents degrés de dépérissement. Pollut Atmos 1986, 28( 1 | 2):270-274.

30. Dixon RA, Paiva NL: Stress-induced phenylpropanoid metabolism. Plant Cell 1995, 7:1085-1097.

31. Muzika RM: Terpenes and phenolics in response to nitrogen fertilization: a test of carbon/nutrient balance hypothesis. Chemoecology 1993, 4(1):3-7.
32. Karolewski P, Giertych MJ: Influence of toxic metal ions on phenols in needles and roots and on root respiration of scots pine seedlings. Acta Soc Bot Pol 1994, 63(I):29-35

33. Peñuelas ], Estiarte M, Kimball BA, Idso SB, Pinter PJ, Wall GW, Garcia RL, Hansaker DJ, LaMorte RL, Hendrix DL: Variety of responses of plant phenolic concentration to $\mathrm{CO}_{2}$ enrichment. J Exp Bot 1996, 47(302):|463-|467.

34. Giertych MJ, Karolewski P: Phenolic compounds distribution along the length of Scots pine needles in a polluted and control environment and its connection with necroses formation. Acta Soc Bot Pol 2000, 69(2): I27-130.

35. Castells E, Roumet C, Peñuelas J, Roy J: Intraspecific variability of phenolic concentrations and their responses to elevated $\mathrm{CO}_{2}$ in two Mediterranean perennial grasses. Environ Exp Bot 2002, 47(3):205-216

36. Loponen J, Ossipov V, Lempa K, Haukioja E, Pihlaja K: Concentrations and among-compound correlations of individual phenolics in white birch leaves under air pollution stress. Chemosphere 1998, 37(8): | 445-| 456.

37. Robles C, Greff S, Pasqualini V, Garzino S, Bousquet-Mélou A, Fernandez C, et al:: Phenols and flavonoids in Aleppo pine needles as bioindicators of air pollution. J Environ Qual 2003 32:2265-227I.

38. Rivero RM, Ruiz JM, Garcia PC, Lopez-Lefebre LR, Sanchez E, Romero L: Resistance to cold and heat stress: accumulation of phenolic compounds in tomato and watermelon plants. Plant Science 2001, 160:315-321.

39. Carriello L, Zanetti L, De Stefano S: Posidonia ecosystem - V. Phenolic compounds from marine phanerogames, Cymodocea nodosa and Posidonia oceanica. Comp Biochem Physiol B: Biochem Molec Biol 1979, 62(2): I59-16I.

40. Zapata O, Mc Millan C: Phenolic acids in seagrasses. Aq Bot 1979, 7:307-317.

4I. Cozza R, Chiappetta A, Petrarulo M, Salimonti A, Rende F, Bitonti M $B$, Innocenti M: Cytophysiological features of Posidonia oceanica as putative markers of environmental conditions. Chem Ecol 2004, 20(321 5-223.

42. Cuny P, Serve L, Jupin H, Boudouresque CF: Water soluble phenolic compounds of the marine phanerogam Posidonia oceanica in a Mediterranean area colonised by the introduced chlorophyte Caulerpa taxifolia. Aq Bot 1995, 52(3):237-242.

43. Dumay O, Costa J, Desjobert JM, Pergent G: Variations in the concentration of phenolic compounds in the seagrass Posidoniaoceanica under conditions of competition. Phytochemistry 2004, 65:32II-3220.

44. Ferrat L, Pergent-Martini C, Romeo M, Pergent G: Hydrosoluble phenolic compounds production in a Mediterranean seagrass according to mercury contamination. Gul Mex Sci 2003, 2 I (I): I08.

45. Cannac M, Ferrat L, Pergent-Martini C, Pergent G, Pasqualini V: Effects of fish farming on flavonoids in Posidonia oceanica. Sci Tot Environ 2006, 370:9|-98.

46. Agostini S, Desjobert JM, Pergent G: Distribution of phenolic compounds in the seagrass Posidonia oceanica. Phytochemistry 1998, 48(4):6II-617.

47. Dumay O, Costa J, Desjobert JM, Pergent G: Variations in the concentration of phenolic compounds in the seagrass Posidonia oceanica under conditions of competition. Phytochemistry 2004, 65:321।-3220.

48. Booker FL, Miller JE: Phenylpropanoid metabolim and phenolic composition of soybean (Glycine max L.) leaves following exposure to ozone. J Exp Bot |998, 49(324): I|9|-|202.

49. Wang $W$, Vignani $R$, Cresti $M$, Scali $M$ : A universal and rapid protocol for protein extraction from recalcitrant plant tissues for proteomic analysis. Short communication Electrophoresis 2006 , 27:2782-2786.

50. Bucalossi D, Leonzio C Casini S, Fossi MC, Marsili L, Ancora S, Wang W, Scali M: Application of a suite of biomarkers in Posidonia oceanica (L.) delile to assess the ecotoxicological impact on the coastal environment. Short communication Mar Environ Res 2006, 62:s327-s331

5I. Laemmli UK: Cleavage of structural proteins during the assembly of the head of bacteriophage T4. Nature 1970 227:680-685 
52. Switzer RCIII, Merrril CR, Shifrin S: A highly sensitive silver stain for detecting proteins and peptides in polyacrylamide gels. Anal Biochem 1979, 98(I):231-237.

53. Expasy [http://www.expasy.org/melanie/]

54. Fresi E, Dolce T, Forni C, Lorenzi C, Migliore L, Rizzelli D, Scardi M: La prateria di Posidonia oceanica (L.) Delile di Talamone (Grosseto, Italia): struttura e stato di salute. In Proceedings of the Conference Le scienze naturali, economiche e giuridiche nello studio e per la gestione degli ambienti acquatici Terrasini, Palermo. CONISMAAIOL; 2004. 18-22 October 2004

55. Boudouresque CF, Mainesz A: Découverte de l'herbier de Posidonie. Cahier Parc Nat Port-Cros, France 1982, 4: I-8I.

Publish with Bio Med Central and every scientist can read your work free of charge

"BioMed Central will be the most significant development for disseminating the results of biomedical research in our lifetime. "

Sir Paul Nurse, Cancer Research UK

Your research papers will be:

- available free of charge to the entire biomedical community

- peer reviewed and published immediately upon acceptance

- cited in PubMed and archived on PubMed Central

- yours - you keep the copyright

Submit your manuscript here:

http://www.biomedcentral.com/info/publishing_adv.asp 